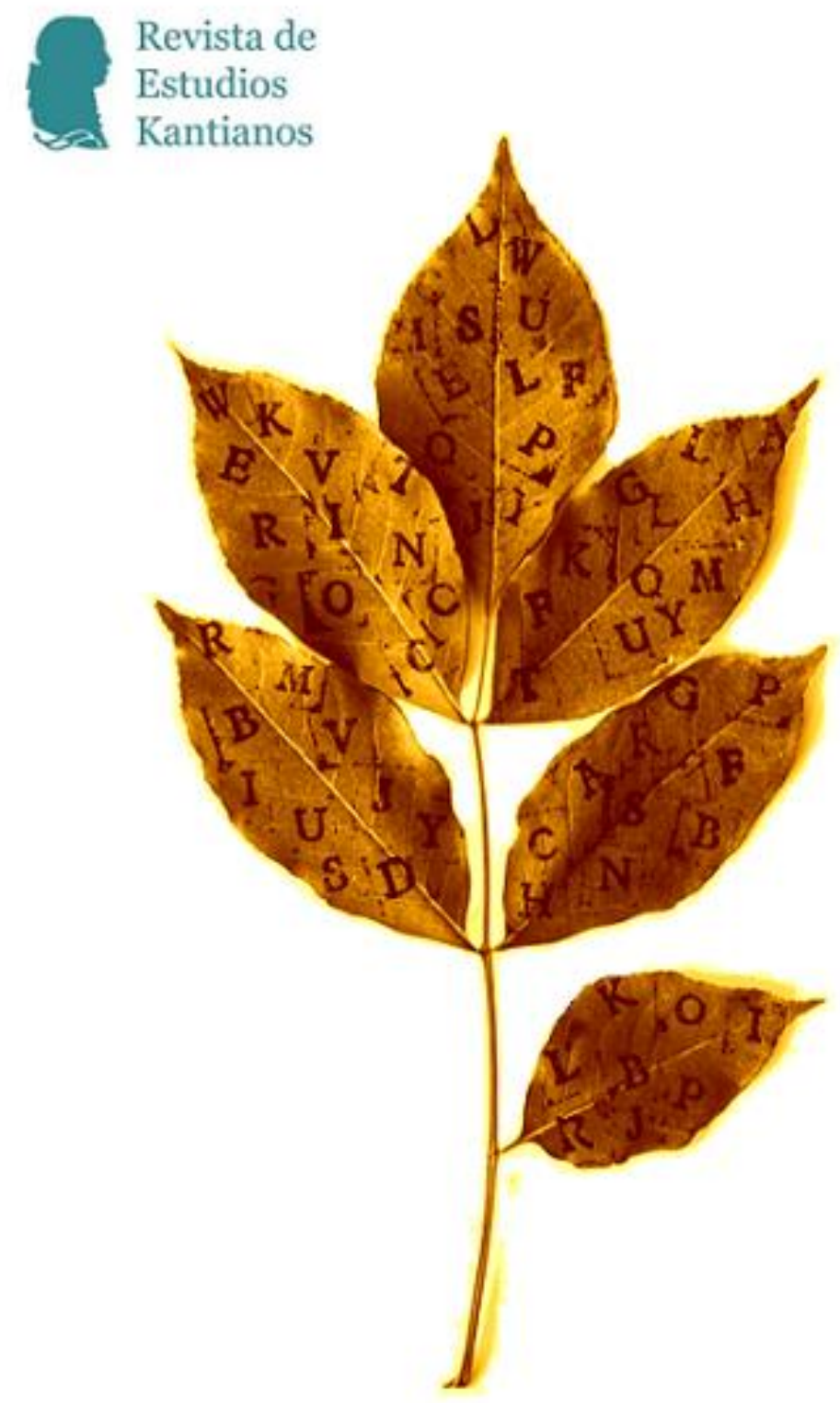


Revista de Estudios Kantianos 


\section{Revista de Estudios Kantianos}

Publicación internacional de la Sociedad de Estudios Kantianos en Lengua Española Internationale Zeitschrift der Gesellschaft für Kant-Studien in Spanischer Sprache International Journal of the Society of Kantian Studies in the Spanish Language

\section{Dirección}

Pedro Jesús Teruel, Universitat de València

pedro.teruel@uv.es

Hernán Pringe, CONICET-Universidad de Buenos Aires/

Universidad Diego Portales, Santiago de Chile

hpringe@gmail.com

\section{Secretario de edición}

Fernando Moledo, Universidad de Buenos Aires - CONICET

fernandomoledo@filo.uba.ar

\section{Secretaria de calidad}

Marcela García, Universidad de Morelia, México

garciar.marcela@gmail.com

\section{Editores científicos}

Jacinto Rivera de Rosales, UNED, Madrid

Claudia Jáuregui, Universidad de Buenos Aires

Vicente Durán, Pontificia Universidad Javeriana, Bogotá

Julio del Valle, Pontificia Universidad Católica del Perú, Lima

Jesús Conill, Universitat de València

Gustavo Leyva, Universidad Autónoma de México, México D. F.

María Xesús Vázquez Lobeiras, Universidade de Santiago de Compostela

Wilson Herrera, Universidad del Rosario, Bogotá

Pablo Oyarzun, Universidad de Chile, Santiago de Chile

Paula Órdenes Azúa, Universität Heidelberg 


\section{Comité científico}

Juan Arana, Universidad de Sevilla

Reinhardt Brandt, Philipps-Universität Marburg

Mario Caimi, Universidad de Buenos Aires

Monique Castillo, Université de Paris-Est

Adela Cortina, Universitat de València

Bernd Dörflinger, Universität Trier

Norbert Fischer, Universität Eichstätt-Ingolstadt

Miguel Giusti, Pontificia Universidad Católica del Perú

Dulce María Granja, Universidad Nacional Autónoma de México

Christian Hamm, Universidad Federal de Santa María, Brasil

Dietmar Heidemann, Université du Luxembourg

Otfried Höffe, Universität Tübingen

Claudio La Rocca, Università degli Studi di Genova

Juan Manuel Navarro Cordón, Universidad Complutense, Madrid

Carlos Pereda, Universidad Nacional Autónoma de México

Gustavo Pereira, Universidad de la República, Uruguay

Ubirajara Rancan de Azevedo, Universidade Estadual Paulista, Brasil

Margit Ruffing, Johannes Gutenberg-Universität Mainz

Gustavo Sarmiento, Universidad Simón Bolívar, Venezuela

Sergio Sevilla, Universitat de València

Roberto Torretti, Universidad Diego Portales, Santiago de Chile

Violetta Waibel, Universität Wien

Howard Williams, University of Aberystwyth

Allen W. Wood, Indiana University

Diseño, revisión de estilo y maqueta

Josefa Ros Velasco, Harvard University, Cambridge (MA)

\section{Corrector}

Aldo Perán, Universidad Diego Portales, Santiago de Chile

\section{Entidades colaboradoras}

Sociedad de Estudios Kantianos en Lengua Española (SEKLE)

Departament de Filosofia de la Universitat de València

Instituto de Humanidades, Universidad Diego Portales

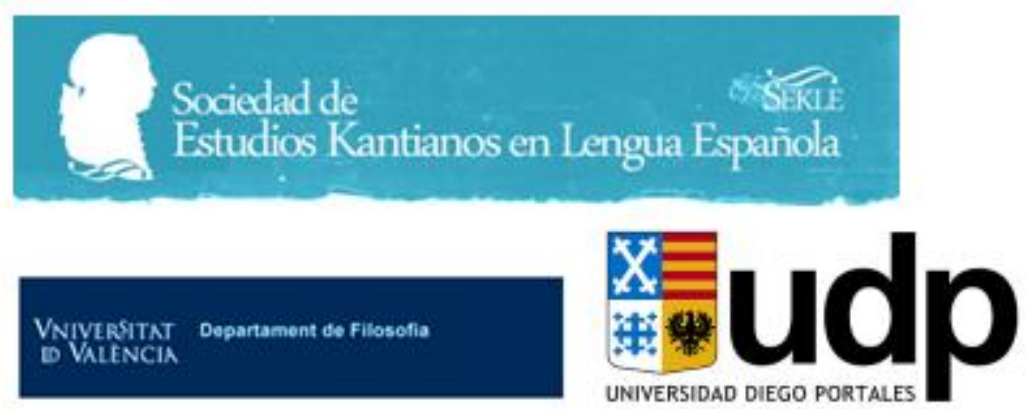




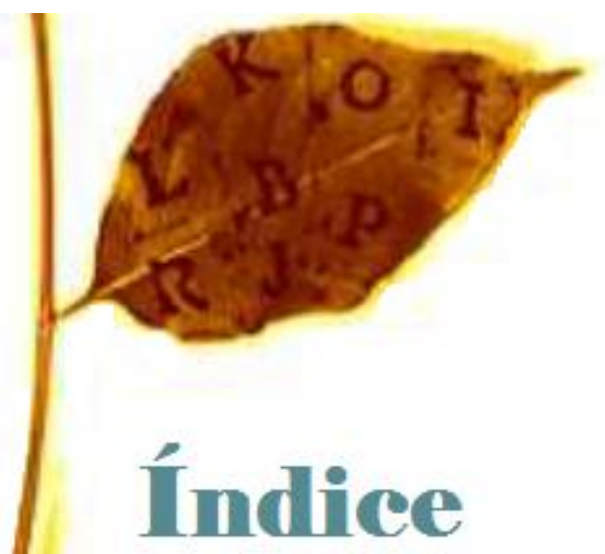

\section{Artículos}

125 Los deberes del amor en la doctrina kantiana de la virtud Bernd Dörflinger DOI 10.7203/REK.2.2.10807

135 Towards a new conception of metaphysics: Lambert's criticism on Wolff's mathematical method

Gesa Wellmann

DOI 10.7203/REK.2.2.10724

149 Acerca del alcance objetivo de las prescripciones metodológicas de la función regulativa de la razón teórica en la Crítica de la razón pura de Kant

Martín Arias Albisu

DOI 10.7203/REK.2.2.8432

168 Formas de autoconciencia en la "Reflexión de Leningrado" Matías Hernán Oroño

DOI 10.7203/REK.2.2.8799

179 Kants Konzeption kosmologischer Freiheit - ein metaphysischer Rest?

Christian Krijnen

DOI 10.7203/REK.2.2.10407

\section{Informe}

196 VII Coloquio Multilateral-Kant 2017

Paula Órdenes Azúa

DOI 10.7203/REK.2.2.10756 


\section{Reseñas}

200 Alfredo Ferrarin: Il pensare e l'io. Hegel e la critica di Kant. Roma, Carocci Editore, 2016, 244 pp. ISBN: 978-88-430-8246-9.

Luigi Filieri

DOI 10.7203/REK.2.2.10764

205 Mario Caimi, Ileana Beade, José González Ríos, Macarena Marey, Fernando Moledo, Mariela Paolucci, Hernán Pringe y Marcos Thisted: Diccionario de la filosofía crítica kantiana. Buenos Aires, Colihue, 2017, 507 pp. ISBN: 978-950-563-450-7.

Miguel Herszenbaun

DOI 10.7203/REK.2.2.10499

210 Paula Órdenes Azúa y Daniela Alegría: Kant y el Criticismo: pasado, presente, y ¿futuro?, Porto Alegre, Editora Fi, 2015, 303 pp. ISBN: 978-85-66923-52-0.

Constanza Terra

DOI 10.7203/REK.2.2.10777

212 Juan Ormeño Karzulovic y Miguel Vatter (eds.): Forzados a ser libres. Kant y la teoría republicana del derecho. Santiago, Fondo de Cultura Económica, 2017, 243 pp. ISBN: 978956-289-149-3.

Cristóbal Olivares

DOI 10.7203/REK.2.2.10762

215 Immanuel Kant (ed. y trad. Gonzalo Serrano): La Deducción trascendental y sus inéditos, 1772-1788. Bogotá, Universidad Nacional de Colombia, 2014, 321 pp. ISBN: 978-95-876195-39.

Pedro Stepanenko

DOI 10.7203/REK.2.2.10763

\section{Semblanza}

220 Juan Adolfo Bonaccini (16 de mayo de 1965 / 10 de julio de 2016)

Daniel Omar Perez

DOI 10.7203/REK.2.2.10783

\section{Convocatorias y normas para autores}

223 Kant en México

DOI 10.7203/REK.2.2.10863

224 IV Congreso Internacional de la SEKLE, Valencia, 2018

DOI 10.7203/REK.2.2.10863

227 VIII Coloquio Multilateral-Kant 2018

DOI 10.7203/REK.2.2.10863

229 Normas para autores

DOI 10.7203/REK.2.2.10863 


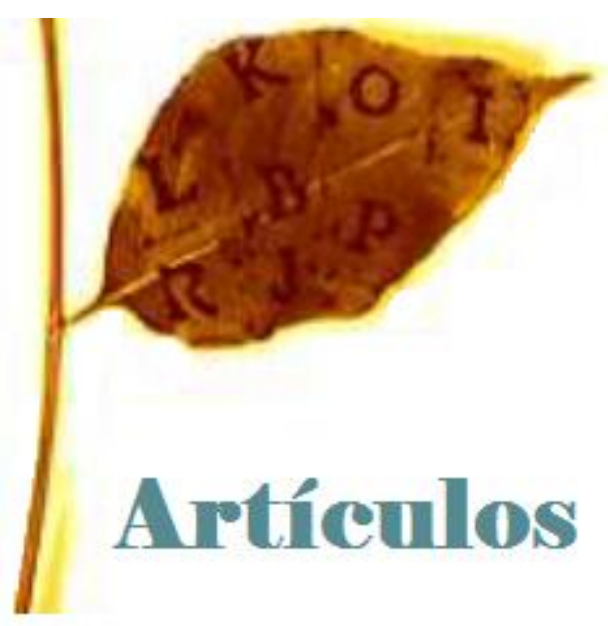




\title{
Towards a new conception of metaphysics: Lambert's criticism on Wolff's mathematical method
}

\author{
GESA WELLMANN ${ }^{1}$
}

\begin{abstract}
This paper discusses Lambert's criticism of Wolff's mathematical method. I take this criticism to consist of two main aspects. Lambert tries on the one hand to revise Wolff's idea of fundamental concepts by providing what he takes to be a more profound theory of concepts.On the other hand, Lambert introduces postulates that regulate the connection between fundamental concepts and account for their application to experience. Both transformations allow Lambert to put forward a novel approach to metaphysics which is essentially oriented towards experience.
\end{abstract}

Key words: Lambert, Mathematical method, Metaphysics, Simple Concepts, Postulates

\section{Hacia una nueva concepción de la metafísica: la crítica de Lambert al método matemático de Wolff}

\begin{abstract}
Resumen
Este artículo aborda la crítica de Lambert al método matemático de Wolff. Dicha crítica se desarrolla en torno a dos aspectos principales. Lambert intenta, por una parte, revisar la idea de los conceptos fundamentales de Wolff ofreciendo lo que considera una teoría de los conceptos más profunda. Por otra parte, Lambert introduce postulados que regulan la conexión entre los conceptos fundamentales y da cuenta de su aplicación a la experiencia. Ambas transformaciones permiten a Lambert presentar un tratamiento novedoso de la metafísica que está esencialmente orientado hacia la experiencia.
\end{abstract}

Palabras clave: Lambert, método matemático, metafísica, conceptos simples, postulados

Introducción

In his main philosophical works, the Organon (1764) and the Architectonic (1771), Johann Heinrich Lambert (1728-1777) points to what he conceives of as a mayor problem in Wolff's metaphysics. According to Lambert's analysis, the latter is of a merely formal nature. ${ }^{2}$ Wolff's metaphysics is, as Lambert sees it, formally correct; however, it does not ensure the validity of its principles beyond the logical domain. In the course of his examination, Lambert provides a diagnosis as to why Wolff fails to ensure such validity. In trying to establish metaphysics as a science, Wolff, according to Lambert, employs a defective method, namely what Wolff conceives of as the mathematical method. ${ }^{3}$ This method results from a translation of the strict demonstration in Euclid's Elements into a theory of

${ }^{1}$ Katholieke Universiteit Leuven, Bélgica.

${ }^{2}$ See Lambert, letter to Kant, February 3, 1766, (AA X: 64). See for a discussion of Lambert's criticism on the formality of Wolff's logic Blomme (2015: 108-111).

${ }^{3}$ As Wolters notes, unfortunately it is not known which books of Wolff Lambert possessed. The auction catalogue of Lambert's estate was only published in one copy, kept by the university library of Breslau and got lost during World War II. See Wolters (1979: 20) 
judgment and serves to determine and connect concepts and propositions. Briefly summarized, Wolff's mathematical method contains three steps: The truth of propositions that require a proof (theorems) is based on the truth of irrefutable propositions (axioms), which in turn are deduced from the correctness of concepts (definitions). ${ }^{4}$ Lambert agrees with Wolff's interpretation of Euclid's method for the most part. ${ }^{5}$ However, he argues that the tripartite argumentation of Wolff only suffices in so far as logic and mathematics are concerned. ${ }^{6}$ It covers, as Lambert sees it, the logical connection between concepts, but fails to provide rules for the application of these concepts to experience. ${ }^{7}$ In order to apply Euclid's theory to metaphysics, it must therefore, as Lambert holds, be reformed.

The aim of the present article is to examine how Lambert revises Wolff's mathematical method in this regard. Lambert's philosophical method has been partially researched in monographs such as Wolter's Basis und Deduktion (1979) and articles such as Basso's "Rien du mathématique dans la methodus mathematica wolffienne" (2008). ${ }^{8}$ However, in my view, previous studies have not sufficiently addressed the impact Lambert's reformed method exerts on his conception of metaphysics. In my interpretation, Lambert revises the mathematical method in view of a new conception of metaphysics, which is mainly concerned with the validity of its judgements in experience. Such a project shows a surprisingly modern approach to the justification of metaphysics as a science and anticipates, as I see it, Kant's notion of metaphysics. ${ }^{9}$ I will argue for this thesis in two steps. Firstly, I will examine Lambert's conception of simple concepts (1). Secondly, I investigate Lambert's theory of postulates (2). As I take it, both conceptions are the decisive tools Lambert uses in order to establish his new notion of metaphysics. Since Lambert's most detailed account of both conceptions can be found in his Architectonic, my paper will mostly rely on this work, while only briefly referring to Lambert's Organon and smaller philosophical writings.

\section{Simple concepts}

Lambert's criticism of Wolff's mathematical method departs from his criticism on those concepts that serve as the ultimate concepts in a definition, namely so-called 'common concepts', such as 'entity'. While Wolff takes these concepts to ground any further axioms of metaphysics, Lambert holds that they cannot account for any content of the axiom they are supposed to ground. Instead, Lambert

${ }^{4}$ Wolff (1733) states: "If I think carefully of everything that is contained in the mathematical method, I find these three main parts (1) that all words [...] are explained by distinct and complete concepts; (2) that all propositions are proven by inferences that are properly connected among each other; (3) that no minor premise is assumed that is not proven before; such that the following propositions are connected with the preceding ones, as one connects an explanation with a preceding one by using words in the former that had been explained in the latter." See for a summary of Lambert's understanding of the mathematical method: Criterium veritatis, $\S 38$

${ }^{5}$ Organon,Aleth. § 1. Hereafter: $\mathrm{Org}$. Lambert's notion of a system stands in the tradition of Aristotle, who influenced both Leibniz and Wolff. Lambert refers to this heritage in his Architectonic, §§ 1-4, while also pointing to what Lambert takes its weaknesses to be. Aristotle, as Lambert states, had arbitrarily gathered the basic concepts, while a metaphysical system would require a systematic deduction of the same.

${ }^{6}$ See Criterium veritatis, $\S \S 3,16,18-20$; the mathematical method, as Wolff proposes the latter, is, as Lambert states, sufficient with regard to geometry and logic since "the concepts [...] are simple and the figures lay before one's eyes" Criterium veritatis $\$$ 18. In logic, according to Lambert, one can identify the laws of thinking by observation, simply by perceiving one's own activity while thinking and concluding. See Lambert (1786), Die Theorie der Parallellinien, \& 5, hereafter: Parallellinien. With his example of parallel lines, Lambert points to the problem of Wolff's definitions. It is, according to Lambert, impossible to deduce a posteriori, i.e. abstracting from all given marks, an axiom of parallel lines. Such a deduction is impossible since geometrical precision and the possibility of drawing into infinity are excluded. See Parallellinien $\S 5$. See on this thesis also Dunlop (2009: $51)$.

${ }^{7}$ This criticism is mainly directed at the foundation of Wolff's chain of proofs, namely his conception of definitions. Lambert rejects definitions as the ultimate starting point for metaphysics for two reasons. Firstly, a definition does not guarantee the validity of what is defined. Secondly, Lambert takes definitions to be only nominations (Benennung), which in themselves cannot prove the correctness of the axiom. Thus, in metaphysics, an axiom cannot be inferred from a definition. See for a similar criticism of the scholastic tradition: Kant (1781/1787) Critique of Pure Reason, A52/B76.

${ }^{8}$ See for comprehensive studies on Lamberts mathematical method: Bierbach (2001); Wolters (1979).

${ }^{9}$ See for a discussion of Lambert's notion of a system: Waibel (2007). See for a discussion of Kant's notion of a system: Critique of Pure Reason (A832/B861- A853/B881); on the same topic, see also: Henrich (2001:94, 101); Zöller (2001:60-72); Kambarte (1969: 109-111). See on the influence of Lambert on Kant's notion of ontology in general: Rivero (2014: 40); Watkins (2009: 231 f.). See on the influence of Lambert on Kant's notion of ontology with regard to the problem of definitions: Brandt (1995: 99). 
suggests taking so-called 'simple concepts' to be the fundamental concepts of metaphysics. In what follows, I will present Lambert's conception of such concepts against the backdrop of his criticism on Wolff (1.1) and discuss the consequences of his theory for his notion of metaphysics in a second step (1.2).

\subsection{Simple Concepts as Fundamental Concepts}

According to Wolff's logic, one important task of philosophy is to account for concepts that are a priori and can serve as the foundation for any empirical concepts. Traditionally the way to find such a priori concepts is by means of abstraction. ${ }^{10} \mathrm{~A}$ concept, according to Wolff's theory, is composed of particular [besondere] marks. The concept of 'horse', for instance, comprises marks such as having four legs, fur, mane, etc. ${ }^{11}$ These marks are empirically attained. In order to arrive at the general concept of mammal, one abstracts from the empirical origin of the marks and discards the marks that the concept shares with other concepts, for example fur. By examining the common marks of all concepts that contain fur, one arrives at the general concept 'mammal'. This concept, in turn, can again be compared with other concepts until one arrives at concepts that do not share any further marks with other concepts, for example 'entity'. ${ }^{12}$ Wolff denotes such concepts as common concepts [Gemeinbegriffe] and takes them to form the foundation of any philosophical system. ${ }^{13}$

Lambert's criticism of Wolff departs from this claim. More precisely, he rejects the idea that common concepts - that is to say most general concepts - can function as fundamental concepts. ${ }^{14}$ On the word of Lambert, the generality of a concept does not guarantee its validity. This means that one cannot, according to Lambert, exclude that a general concept is in itself a contradictory concept. ${ }^{15}$ One cannot do so because, in Lambert's eyes, any concept that has been arrived at by means of abstraction is a composed concept. ${ }^{16}$ For example, the concept 'entity' contains, according to Lambert, other concepts, such as 'the one', 'the true', 'the good'. Now, the principle of non-contradiction can be applied to such composed concepts only as a negative criterion of truth. If one finds a contradiction in a concept, one can be certain that the concept is impossible and thus not true. However, not finding such a contradiction does not guarantee that the concept is

\footnotetext{
${ }^{10}$ With respect to abstraction, Wolff refers to Aristotle and Leibniz. On the relation between Wolff and his predecessors as well as Wolff's deviations from Leibniz, see Ros (1989: 133-154)

${ }^{11}$ Lambert takes over this definition of a concept. In a letter to Kant, he states that a concept is "a combination of particular marks". Lambert'sletterto Kant, February 3, 1766, (AA X: 64).

${ }^{12}$ See Wolff (1713) Vernünfftige Gedancken von den Kräfften des menschlichen Verstandes $\S \S 1-114$. Hereafter: Kräfte des Verstandes. See on the equivocation of common concept [Gemeinbegriff] and general concept [Allgemeinbegriff]: Wolff (1729) De differentia intellectus systematici \& non-systematici, p. 255. Hereafter: De differentia.

${ }^{13}$ De differentia, $\$ 11$. I will not discuss the difference between general concepts (arrived at by means of abstraction) and universal concepts (arrived at by means of analysis) here, nor Lambert's rather obscure discussion of the importance of the method of abstraction for scientific cognition and its relation to the anatomic method. See for this discussion: Criterium Veritatis, § 3; Arch. § 7; Org., Dian. $\S \S 6,17,32-47,59,60,633,634,639,643$; Org. Aleth. $\S 9$. See for a discussion of Lambert's account of general concepts: Bierbach (2001: 138).

${ }^{14}$ Lambert's criticism is directed at the fact that by means of abstraction, Wolff arrives at nominal definitions whereas the contents of these definitions, i.e. the real definitions, are lacking. See Lambert, letter to Kant, February 3, 1766, (AA X: 64). Wolff, for his part, stresses the difference between nominal and real definition, while criticizing Descartes for having given only nomina definitions of the soul whereas as he, Wolff, provides the real definition of the latter. See Kräfte des Verstandes, $\S \S 48,54$. As Rivero (2014: 25) suggests, Lambert's criticism of Wolff's ontological concepts resembles Kant's criticism of Wolff's mathematical method in his Preisschrift (1763). Metaphysics, as Kant conceives of it, does not start from definitions but rather from experience (UD AA II, 276). Lambert changes his view on fundamental concepts slightly between his Criteriumveritatis and the Organon. See on this: Wolters (1979: 67).

${ }^{15}$ See Organon, Dian. $§ 110$.

${ }^{16}$ See Anlage zurArchitektonik, I, § 14. Hereafter: Arch. Lambert's criticism is mainly directed against the concept of 'entity', which Wolff takes to be simple. In a letter to Holland, he states that the 'entity' is "the most composed [concept of all concepts] Because it contains in itself all kinds of fundamenta divisionum and subdivsionum", that is to say, apart from 'the one', 'the true' and 'the good', 'quale', 'quantum', 'numerabile', 'existentiae capax' and "countless others for which language don't even have words". Lambert's letter to Holland, April 12, 1765, (1782: 33). See also Organon, Dian. \$ 110. Bierbach (2001: 137, 138) stresses the important difference between Sache or Gegenstand and Ding, both referring to the Latin ens. Sache is a broader notion than Ding and can refer to a fact in general, whereas Ding refers to an entity (object). I will follow the Cambridge translation of the Critique of Pure Reason and translate Gegenstand with 'object' and Ding with 'entity'. As Bierbach rightly observes, Lambert seems to use Sache and Gegenstand mostly synonymously; hence I will translate Sache with 'object'. See for composed concepts: See Criterium Veritatis, $\$ 7$.
} 
possible. Because a concept can be contradictory and thus impossible even if subjective reasons hinder us from finding such contradictions. ${ }^{17}$ Since common concepts cannot ensure that they are valid, Lambert concludes, they are not suitable for serving as fundamental concepts to metaphysics.

The principle of non-contradiction, according to Lambert, can only form a 'positive' criterion of truth if the concept 'cannot' contain any contradiction a priori. Concepts that meet such a demand are those concepts that contain only one mark, since "they do not contain any inner contradiction in themselves (an sich) since in order to contradict, several, or at least two parts are required". ${ }^{18}$ Concepts that contain only one particular mark are called 'simple concepts' and represent, as Lambert holds, the fundamental concepts of a scientific system. According to his argumentation in both the Organon and the Architectonic, they can be found in marks that cannot be dissolved into further marks. As they do not share a single mark with other concepts, Lambert describes simple concepts as "individual". ${ }^{19}$ This, as Lambert stresses, is in contrast to Leibniz and Wolff, whose general concepts only account for genera and species. ${ }^{20}$ However, Lambert abolishes neither Wolff's method of abstraction nor his theory of general concepts, but instead he seeks to ground the latter in what he takes to be more basic concepts.

Given that abstraction only leads to what Lambert considers as general concepts, simple concepts must, according to Lambert, be discovered by a different means. ${ }^{21}$ The method Lambert introduces - and which he refers to as "anatomic" - consists in demonstrating the "genealogy of concepts". ${ }^{22}$ As the name already implies, Lambert tries to investigate into the very origin of concepts and of simple concepts in particular. In line with Locke, he takes this origin to lie in experience. ${ }^{23}$ Since no contradiction can occur in a simple concept, its possibility is immediately given. Therefore, the possibility of simple concepts does not depend on experience. ${ }^{24}$ However, Lambert stresses that we, as finite beings, are dependent on experience in our search for simple concepts. ${ }^{25} \mathrm{We}$ experience, for instance, the impression of physical force or color, both of which Lambert denotes as simple concepts. ${ }^{26}$ Simple concepts are thus "taken from phenomena (Schein)" ${ }^{27}$

${ }^{17}$ See Criterium Veritatis, $\$ 10$

${ }^{18}$ Arch. $\$ 7$.

${ }^{19}$ Lambert, letter to Kant, February 3, 1766, 22 [37], p. 47.

${ }^{20}$ Lambert, letter to Kant, February 3, 1766, 22 [37], p. 47. See on the relation between Leibniz and Lambert: Baxmann (2000: 243, 244); Siegwart (1988; XVII).

${ }^{21}$ See Lambert's letter to Holland, April 21, 1765, (1782: 23, 24, 32, 33). Normally, Lambert distinguishes between a 'synthetic' method, by means of which simple concepts can be discovered, and an 'analytic' method. Lambert mostly identifies analytic method and abstraction. The aim of this latter method is to find similarities among concepts. Such similarities result, as Lambert sees it, in nominal definitions, such that philosophy, if based only on this method, would be turned into a dictionary. In particular he criticizes Wolff for not discussing simple concepts such as space, time and duration. See Arch. $\$ 13$. However, Lambert is not always consistent with regard to his usage of 'analytic' and 'synthetic'. In Arch. § 51 and Criterium veritatis § 37, he claims for instance that the analytic method had lead him to the discovery of simple concepts.

${ }^{22}$ Arch. $\S 51$. See also Lambert's letter to Kant, February 3, 1766, (AA X: 65). With his anatomic method, Lambert tries to apply the mathematical method, which until then had been used only with regard to the connection of propositions, to concepts. See Arch. § 23. Just as propositions, so too concepts, according to Lambert, can be distinguished into fundamental and doctrinal ones [Lehrbegriffe], while the main task consists in discovering fundamental concepts. See Criterium veritatis $\$ \S 25,37,38,39$. I will not discuss the division of all concepts into simple concepts of experience [Erfahrungsbegriffe] and doctrinal concepts [Lehrbegriffe] here in more detail. Lambert derives the latter from the former. The distinction between these concepts reflects the distinction between theorems and axioms. Lambert's theory of concepts in general is in line with Wolff's analysis of concepts in so far as composed concepts are reduced to simple ones by means of the "analytical method". See Criterium veritatis $\S 37$. Lambert highlights, however, the importance of clearly distinguishing between the classes of concepts (this point is mainly stressed in the Architectonic) in order to enable a pure derivation. See Criterium veritatis $\S 44$.

${ }^{23}$ See Org., Vorrede. See for the origin of simple concepts in sensibility also Arch. $\S 153$. Lambert conceives of his project as uniting elements of both Wolff's and Locke's philosophy. See Org. Vorrede. As Wolters (1979: 111) rightly points out, the view according to which concepts originate in sensual perception can also be found in parts of the scholastic tradition and, hence, Aristotle (cf. Thomas Aquinas' peripatetic axiom: "Nothing is in the intellect that was not first in the senses" De veritate, q. 2 a. 3 arg. 19).

${ }^{24}$ See Org., Dian. $\$ 656$.

${ }^{25}$ According to Lambert's discussion in Org., Aleth. § 1, simple concepts are internal to the mind [liegenim Gemüt] and must be activated by means of experience. On this, see Leibniz's introduction to his Nouveaux Essais, which Lambert did not know, since they were published only in 1765 .

${ }^{26}$ Arch. \& 46. In $\mathrm{Org}$. \& 234 a, Lambert states furthermore that God has to be understood as the source of all simple concepts. The function of theology is, according to Lambert, to prove this thesis. 
Lambert discusses the advantages of the empirical origin of simple concepts in his correspondence with Kant. Discussing Kant's Dissertation, in what is arguably his most influential letter to Kant, Lambert agrees with Kant on the difference between the sensual and the intellectual sources of our cognition. For Lambert, it is clear that

human cognition [...] falls into the old [distinction between] phaenomenon and noumenon and, according to this distinction (Einteilung) arises from two entirely distinct and as it were heterogeneous sources, such that what comes from the one source can never be deduced from the other. ${ }^{28}$

However, against Kant's approach in his Dissertation, Lambert stresses the importance of concepts that are taken from experience, since "in ontology, it is very useful to analyze as well those concepts that are taken from appearance, since their theory must be applied to phaenomenis again". ${ }^{29}$ In other words, Lambert holds that simple concepts must be discovered by means of experience because he aims to avoid Wolff's problem, namely ending up with a purely formal set of ontological concepts. ${ }^{30}$ If ontology is based on concepts that are taken from experience, on the other hand, Lambert is confident that it can apply its principles to experience again. ${ }^{31}$

It should be stressed that this approach is based on a notion of a priori that differs from that of Kant and others. ${ }^{32}$ 'A priori' in Lambert's sense does not exclude empirical input. Simple concepts have an empirical character, since it is only by means of the anatomic method that they are discovered. Their legitimacy, however, is not based on experience but rather on their having only one mark. ${ }^{33}$ As they are valid independently of experience, they are, as Lambert states, a priori. ${ }^{34}$ Thus, Lambert is clearly sensitive to the problem that metaphysics should take experience into account while at the same time remaining a science of a priori truths rather than of empirical concepts. In line with this, the fact that simple concepts are discovered by means of experience does not, in Lambert's view, limit their scope to the empirical world. Rather, simple concepts can be transferred to the socalled intellectual world, i.e. to the understanding and the will: "The designations of objects in the intellectual world are taken from the objects in the sensual world (Körperwelt)". ${ }^{35}$ If I experience physical force by lifting a weight, for example, I can extend the concept of force to the intellectual world, such that we can speak of the force of the understanding or the force of the will. ${ }^{36}$ In such a way, simple concepts can be freed from a merely sensual context. ${ }^{37}$

${ }^{27}$ Arch. $\$ 43$.

${ }^{28}$ Lambert's letter to Kant, October 13, 1770, (AA X: 105).

${ }^{29}$ Lambert's letter to Kant, October 13, 1770, (AA X: 108). Kant will, as Beck (1969: 127) argues, develop his theory of space and time in virtue of Lambert's objection in this letter.

${ }^{30}$ With regard to Lambert's conception of empirically given objects and the importance of the latter for metaphysics as an a priori science, I hold a position between two authors: against Wolters (1979), I hold that Lambert was aware of the problem of an object in its empirical sense and its fundamental difference to the object of logic. Against Beck (1969), I hold that Lambert was not aware of the dimension of this differentiation, as he did not reflect on the consequences of his theory.

${ }^{31}$ Wolters (1969: 76), who argues that Lambert's aim was to establish conditions for the natural sciences, interprets Lambert's notion of experience as being "lebensweltlich". Lambert's simple concepts, according to Wolters (1979: 73-82), are taken from a notion of experience that coincides with historical knowledge, i.e. common knowledge based on observation. Although I agree that Lambert puts forward such a notion of experience, I take it to be inadequate precisely in the case of simple concepts. There, Lambert explicitly refers to an individual sensual impression. Cf. Arch. § 29 as well as Org. Dian. § 551

${ }^{32}$ See on the different use of "a priori" in Lambert and Kant Wolters (1979: 77-79).

${ }^{33}$ See Arch. \$ 24; according to Wolters, Lambert introduces a new meaning of a priori insofar as he uses the term to describe a scientific context (in contrast to the prior syllogistic use of a priori). See on this Wolters (1979: 77).

${ }^{34}$ It is difficult to decide whether Lambert was aware of the special status of simple concepts. Wolters (1979: 77) explains the status of simple concepts by pointing to Lambert's notion of a priori, which does not exclude any empirical impact. Furthermore, Wolters (1979: 56; 76-81) stresses that Lambert's concept of experience (and consequently his notion of 'empirical') differs from that of what is commonly understood as empiricism. In general, I agree with this interpretation. However, as has become clear from what I have discussed above, Lambert does distinguish between what could be called "empirical" and "a priori" cognition, for instance in the letter of 1770 to Kant on human cognition that I just cited. Beck (1969: 127) takes this letter to be of utmost importance precisely with respect to the influence of Lambert on Kant with regard to the problem of the relation between a priori concept and empirically given objects.

${ }^{35}$ Arch. § 29, see on that also Arch. § 97.

${ }^{36}$ See Arch. \$ 29; Org. Dian. \& 551.

${ }^{37}$ Lambert only transfers certain simple concepts to the intellectual world, namely those that he calls 'fundamental concepts'. 
In the Organon and the Architectonic, Lambert presents a loosely collected list of simple concepts that correspond for the most part with Locke's simple ideas. ${ }^{38}$ These simple concepts consist first of all in eight so-called simple fundamental concepts, namely solidity, existence, duration, extension, force, movability, unity and identity. ${ }^{39}$ Next to these fundamental concepts, other simple concepts are taken "from sensual appearance (Schein)". These include color and sound, verbs, adverbs, prepositions and conjunctions, that is, concepts such as 'being', 'equal', 'through' and 'because' ${ }^{40}$ Since Lambert takes all of these concepts to be independent from experience in the sense discussed above, these concepts serve as the foundation of all a priori cognition in the Organon and the Architectonic.

\subsection{Simple Concepts and Ontology}

Having demarcated a group of simple concepts, namely fundamental concepts, from the rest, Lambert takes them alone to be suitable to provide the foundation of scientific cognition. Simple concepts in general are a priori and are used in a priori cognition. Simple fundamental concepts, on the other hand, serve as the foundation of 'all' a priori cognition altogether since any composed concept that is used in scientific cognition can be deduced from a combination of fundamental concepts. ${ }^{41}$ In order to give an overview on this latter function, Lambert designs what he calls the 'table of correlations'. ${ }^{42}$ This table, as Lambert states, denotes a system that presents the foundation of all a priori cognition. It does so by showing two things. Firstly, it shows how fundamental concepts can be combined:

Since simple concepts are the first foundation of our cognition, and since everything of composed concepts, inasmuch as we represent the latter [...], can be dissolved into simple concepts; simple concepts, separately and combined among each other, form a system which necessarily contains all first foundations of our cognition. ${ }^{43}$

Secondly, the table shows which combinations of fundamental concepts underlie which a priori science. ${ }^{44}$ Unfortunately, it is not quite clear how Lambert arrives at the relations between concept and science. He only casually remarks: "Furthermore, every column presents a special theory and science". ${ }^{45}$ Lambert differentiates sixteen of these a priori sciences, among others geometry, ontology and dynamics, which he arranges as follows: ${ }^{46}$

${ }^{38}$ See Arch. § 9; cf. Org., Dian. § 646, Aleth. § 38; In his Organon, Dianologia § 653, Lambert explicitly refers to Locke's distinction between simple concepts (taken from immediate sensation) and general concepts (arrived at by abstraction, viz. the understanding). Lambert does not exactly follow Locke`s division of simple concepts into four classes. In the table of Locke's concepts that follows I highlight those concepts that Lambert considers to be simple concepts, or as Locke puts it, simple ideas: 1) ideas which come through one sense organ (color, sound, smell, etc.); 2) ideas which come through more than one sense-organ (extension, shape and motion, solidity); 3) ideas which come from an inner faculty (thinking, volition, memory, judgment, knowledge, faith). This does not imply that those ideas are a priori. The observation of our mental operations presupposes that the mind operates with contents given by experience; 4) ideas which come from both external and internal faculties (pleasure, pain, being, power, unity and succession). Cf. Locke, An Essay Concerning Human Understanding, especially book II and III. Accordingtohis own statement, Lambert readLocke'sEssay Concerning Human Understanding: "I read Wolff, Von den Kräften des menschlichen Verstandes, Malebranche, Von der Erforschung der Wahrheit, Locke, Gedanken vom menschlichen Verstande. The mathematical sciences, in particular algebra and mechanics, provided me with distinct and thorough examples in order to confirm the rules I learned." Lambert, letter of 1750, cited in: Krienelke (1909: 11). As Wolters (1979: 19, 56) argues, it is improbable that Lambert knew the works of Hume.

${ }^{39}$ See Arch. § 49. In his enumeration, Lambert lists 10 fundamental concepts, limits their discussion in the Architectonic, however, to eight, since "the first [namely consciousness] can be found in any [a priori science], the latter [namely the will] on the other hand has its own object, namely the good and thus belongs particularly to agathology or the doctrine of the good". Arch. § 52 .

${ }^{40}$ Arch. $\$ 46$.

${ }^{41}$ See Org. Dian. § 653; See also Arch. § 23; Org. Dian. § 623.

${ }^{42}$ Arch. $\$ 71$.

${ }^{43}$ Arch. $\$ 74$.

${ }^{44}$ See Arch. $\$ 53$.

${ }^{45}$ Arch. $\$ 71$.

${ }^{46}$ See Arch. \$ 74. Legend:

* the fundamental concept (der zum Grunde gelegte Begriff)

$=\quad$ a concept that is necessarily connected to the fundamental concept

the object of the fundamental concept

the compared concept 


\section{Korrelate der Grundlehren}

\begin{tabular}{|c|c|c|c|c|c|c|c|c|c|c|c|c|c|c|c|}
\hline & 1 & 2 & 3 & 4 & 5 & 6 & 7 & 8 & 9 & 10 & \begin{tabular}{l|l}
11 & 1
\end{tabular} & 121 & \begin{tabular}{l|l}
3 & 1 \\
\end{tabular} & & 16 \\
\hline Solidität & + & - & $\approx$ & $*$ & 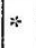 & $=$ & - & - & & & -- & $-1=$ & $==$ & & - \\
\hline Existenz & - & - & - & - & & $\%$ & - & - & & & & & & & \\
\hline Dauer & - & - & - & - & & $=$ & $\approx$ & $*$ & $*$ & & & - & - & $=$ & $=$ \\
\hline Ausdehnung & - & - & $=$ & & - & & & - & & $\%$ & $* *$ & & - & $=$ & $=$ \\
\hline Kraft & + & - & - & - & - & $=$ & - & & & & - & $-*$ & * & & - \\
\hline Beweglichkeit & - & - & - & & & & & & & & & - & - & * & $*$ \\
\hline Einheit & - & $*$ & - & & - & $=$ & & & - & - & - & - & - & - & - \\
\hline Identität & $*$ & - & - & & & $=$ & & - & & & & & & & \\
\hline & 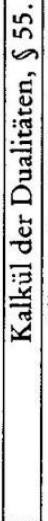 & 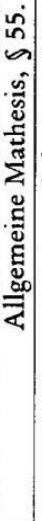 & 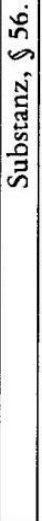 & 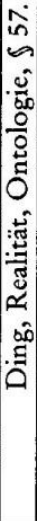 & 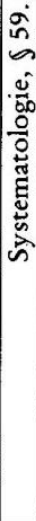 & 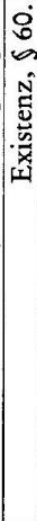 & 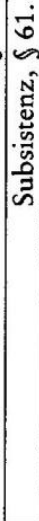 & 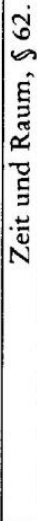 & 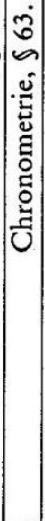 & 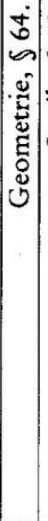 & 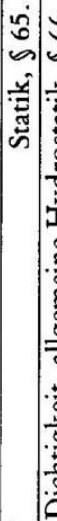 & 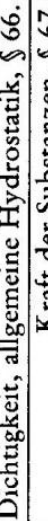 & 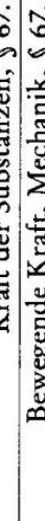 & 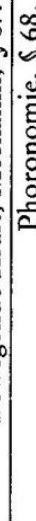 & 象 \\
\hline
\end{tabular}

As I see it, this table nicely illustrates Lambert's conception of metaphysics in general and his conception of ontology in particular. Firstly, it affirms what I argued for above, namely that for Lambert, ontology is based on a combination of simple concepts taken from experience. More precisely, Lambert bases his ontology on the simple concept of solidity. I take the last part of the Architectonic to develop such an ontology, more precisely the second, third and fourth part, in which Lambert discusses the ideal', 'the real' and 'magnitude'. ${ }^{47}$ In these chapters, Lambert investigates the fundamental concepts, which he established in the first part of the Architectonic, with regard to their application in philosophical cognition of solid objects. ${ }^{48}$ This is particularly remarkable with regard to

In total, Lambert refers to 16 sciences as 'a priori sciences', all of them based on the eight fundamental concepts. In his Criterium Veritatis, however, Lambert presents two forms of immediate truths apart from fundamental concepts: the Cartesian cogito and the sensation of harmony with respect to systematically structured cognition (\$ 79). In the Organon and the Architectonic, these three elements can be found as well. However, as Lambert focuses, except for a few exceptions, on a discussion of simple concepts, I will only take the latter into account. Even though Lambert admits that the table might contain more than 16 columns, he takes the foundational science to be constant and evident. Future generations could add combinations of concepts, the simple concepts, however, are unchangeable, and the possibility of the combination is thus limited (Cf. Arch. $\$ \$ 54,69$ ).

${ }^{47}$ See Arch. Vorrede, X and XVI. See also Arch. § 161. I take Lambert's Architectonic to provide an alternative propaedeutic to a future system of metaphysics, which Lambert planned to establish. See Über die Methode, § 53. In this sense, the Architectonic fulfills a twofold function: the first part of the Architectonic provides a doctrine of method; the second part delivers parts of Lambert's system. See on Lambert's conception of architectonic: Manchester (2003: 187-207). See on the preparatory role of Lambert's Architectonic in particular: Wellmann (2017).

${ }^{48}$ The second part of the Architectonic, which I take to deal with Lambert's ontology, is based on another table, the so-called table of axioms. Solidity is primarily ascribed to impenetrable bodies (see Arch. $\$ \$ 48,57,90,92-94)$. However, Lambert transfers the concept also to the intellectual domain: "in such a way, the concept of solidity becomes transcendent and one calls a cognition 
the former function of ontology. Traditionally, the three objects of metaphysics, God, the soul and material things constitute the threefold division of special metaphysics in theology, psychology and cosmology. On this account, ontology serves as a fundamental science to these objects by treating an object in general. ${ }^{49}$ Lambert, on the other hand, releases ontology from this preparatory function for special metaphysics. Ontology is not defined as a fundamental science 'for' some discipline anymore, but claims for itself the status of an independent science of that which is solid. ${ }^{50}$

Affirming this new role of ontology, the table shows secondly that Lambert did not intend to include the disciplines of special metaphysics - rational psychology, cosmology and theology nor, for that matter, logic or agathology in his system of a priori sciences. Even though Lambert takes all of these disciplines to be based on simple concepts, apparently, he considers them to be of a different kind than the a priori sciences mentioned in the table. ${ }^{51}$ Since he describes the table as giving an overview on all a priori sciences, it is very likely that Lambert did not consider them to become sciences at all. To ontology, on the other hand, Lambert ascribes a similar status as to any of the other sciences that are listed in the table. ${ }^{52}$ Thus, Lambert seems to be optimistic that ontology could, by means of his theory of simple concepts, become a proper science. However, on the basis of simple concepts alone, ontology, as Lambert sees it, cannot be established. As the following section aims to show, Lambert takes the application of these concepts to experience to be an equally important element.

\section{Postulates}

The previous section discussed a first aspect of Lambert's criticism of the mathematical method, such as it is advocated by Wolff. This criticism consists in rejecting definitions as the basis of ontology. With his version of simple concepts, Lambert tries to avoid what he understands as purely formal cognition. ${ }^{53}$ The current section discusses a second point of criticism, which builds on this thought. Wolff's system, according to Lambert, consists in the analysis of, and connection between, general concepts. This connection is regulated by logical principles such as the principle of non-contradiction. Lambert, on the other hand, tries to base these merely logical principles in more basic ones to which he refers as postulates and that he takes to arise directly from simple concepts. Hence, Lambert criticizes not only the formality of nominal definitions, but also the exclusive use of logical principles. In order to elucidate this claim, I will first examine how Lambert conceives of postulates in general (2.1) and then clarify the postulate's function with regard to ontology (2.2).

\subsection{Postulates as Principles}

As argued above, the ultimate function of simple concepts is to ground those sciences that Lambert notes in his table of correlations. ${ }^{54}$ Building up a science on the basis of such simple concepts requires, as Lambert states, that they are connected. The problem of connection arises due to the specific nature Lambert ascribed to simple concepts:

'solid' if it is not only dreamt but real, scientific and thorough (gründlich) and if its inferences and conclusions are necessary" Arch. $\S 93$. As far as I can see, there is no indication though that the table of axioms deals with such a broad notion of solidity.

${ }^{49}$ See Arch. $\$ 19$. See on the structure of metaphysics in the $17^{\text {th }}$ and $18^{\text {th }}$ century: Vollrath (1962).

${ }^{50}$ See on the founding function of ontology in scholastic philosophy: Vollrath $(1962: 263,267)$.

${ }^{51}$ The Organon and the Architectonic treat the axioms of special metaphysics though. Cf. Org. Aleth. $\S 247$. On agathology, see Arch. § 52; on special metaphysics, see Org. Aleth. §§ 234 a, 247; on logic see Über die Methode.

${ }^{52}$ See on the difference between ontology and special metaphysics: Org. Aleth. $§ 195$.

${ }^{53}$ Lambert, letter to Kant, February 3, 1766, (AA X: 64). Rivero (2014: 33) argues that Lambert's criticism of the formality of Wolff's architectonic refers to the fact that Wolff's principles only refer to ontology, while Lambert's principles take other a priori sciences into account as well. Although I agree that Lambert's architectonic is not only designed to prepare ontology, I take such an explanation to blur Lambert's original intention behind avoiding formality: namely to prepare an ontology that can be applied to experience. See on this subject: Lambert's letter to Holland, April 21, 1765, (1782: 31), as well as: Arch. §§ 18, 239.

${ }^{54}$ See Arch. Vorrede VII. 
It is important to closely determine the proposition [...] of the absolute (uneingeschränkt) manifoldness of composed concepts and entities, since simple concepts are different as such and therefore provide the first grounds of heterogeneity (Ungleichartigkeit) [...]. As they can be put together, determined and connected among each other, the question arises in how far one has a choice to maintain certain or several determinations, connections and relations. ${ }^{55}$

As the quote makes clear, simple concepts are inherently heterogeneous [an sichverschieden] and it is their combination that serves as the first ground of any heterogeneity [Ungleichartigkeit] and 'manifoldness' of complex concepts. ${ }^{56}$ The theory of simple concepts is therefore in need of a principle that guarantees that the simple concepts can be applied to any given manifold in a valid way. ${ }^{57}$ This task cannot be fulfilled by logical principles alone, as Wolff proposes. Lambert elaborates on the deficiency in this regard in his second letter to Kant. ${ }^{58}$ In 1766, Lambert draws Kant's attention to the question as to "whether and to what extent the cognition of the form leads to cognition of the matter of our knowledge". ${ }^{59}$ On Lambert's interpretation, logical principles, such as the principle of non-contradiction, cannot guarantee the validity of any judgements. ${ }^{60}$ The application of a simple concept to a given manifold can, as Lambert sees it, only be executed by a principle that is not purely formal. And it is, according to Lambert, only postulates that fulfill this requirement. Since postulates are laws that stem from simple concepts, they differ in origin from logical laws. It is, as Lambert writes to Kant, "matter that gives postulates"; or, as the Architectonic states, postulates are "taken from the objects themselves". ${ }^{61}$

In line with his general approach, Lambert claims to follow Euclid here. As he remarks in his first letter to Kant, the theory of postulates is just what is missing if one is to strictly following the Euclidian method: "Wolff implemented about half of the mathematical method into philosophy. If the other half is implemented as well, we gain what we desired". ${ }^{62}$ Trying to provide this 'other half', Lambert's theory of postulates constitutes a second addition to Wolff's tripartite version of the mathematical method: After having introduced simple concepts which are supposed to precede definitions, Lambert presents postulates which are supposed to precede axioms. While Wolff, according to Lambert, tries to justify the axiom directly from a definition, it is clear from Euclid's theory that an intermediate step is required: Between definitions and axioms, postulates must be inserted. Thus, Euclid's elaborations on geometrical figures show, according to Lambert, that "every definition, before being proven, is an empty hypothesis". ${ }^{63}$ The Euclidean definitions are denotations, while their proofs can only be provided by a postulate. Thus, for example, the definition "a line is a

\footnotetext{
${ }^{55}$ Arch. $\$ 156$.

${ }^{56}$ See on the problem of the relation between simple and composed concepts also Lambert's letter to Kant from February 3, 1766 , (AA X: 65). See also Arch. $\S \S 23 ; 122 ; 135$, where Lambert stresses the importance of the combination of simple concepts with regard to composed concepts.

${ }_{57}^{5}$ See Arch. $\$ 135$.

${ }^{58}$ Further passages where Lambert discusses the defects of Wolff's method are: Lambert's letter to Holland (1782: 29), see also Org. Aleth., § 242; Arch. § 15.

${ }^{59}$ Lambert's letter to Kant, February 3, 1766, (AA X: 64). See also: Lambert's letter to Kant, November 13, 1765, (AA X: 52); Lambert's letter to Kant; letter to Holland, 1782, (AA X: 31). See also: Arch. $\S 1$ 14, 18, 239. I am simplifying Lambert's argumen here, which runs as follows: the form, i.e. logical principles, lead us to simple concepts, which provide us with content. If this content is to be used in a science, simple concepts must be combined. This takes place by means of postulates. Cf. Lambert's letter to Kant, February 3, 1766, (AA X: 46).

${ }^{60}$ The problem Lambert formulates here might recall the criticism Kant puts forward against scholastic philosophy. Indeed, some scholars, such as Beck, have pointed out that Lambert's criticism of the purely formal character of metaphysics had a great impact on Kant's development of transcendental philosophy. (Cf. Brandt (1995: 98, 99), Beck (1969: 127), Rivero (2014: 33)). These scholars stress the impact Lambert might have had in pointing Kant to the problem of form and matter. Furthermore I take it that Lambert might have had an influence in justifying the use of 'non-classical' principles, such as postulates or schemata, by pointing to their ability to apply a concept.

${ }^{61}$ The full quote reads: "the form gives principles, the matter axioms and postulates". Lambert's letter to Kant, February 3,1766 , (AA X: 65). See on the relation between matter and axioms in contrast to principles that only refer to the definition of a thing: Arch. $\$ 43$.

${ }^{62}$ Lambert'sletterto Kant, November 13, 1765, (AA X: 54)

${ }^{63}$ Die Theorie der Parallellinien, $\S 6$. See on Lambert's criticism on Wolff with respect to lacking postulates: Arch. $\S \S 12,15$. In the context of this paper, I cannot examine in how far this criticism is justified. See on a discussion of this subject: Basso (2008: 109-121).
} 
breadthless length" must be proven by the postulate "to produce a finite straight line continuously in a straight line". ${ }^{64}$ In Euclidean geometry, one must first draw a single line in order to prove the applicability of a general rule that applies to all lines, that is to say all special cases. ${ }^{65}$

Lambert takes the postulates he finds in Euclid to differ from any other principles because of their "practical" nature. ${ }^{66}$ Whereas Wolff, on Lambert's account, only used descriptive laws in order to connect his fundamental concepts, he attributes a prescriptive task to the postulates. In his Elements, Lambert remarks, Euclid proves that a line is possible by demonstrating that one can 'produce' a line. ${ }^{67}$ The conclusive force of postulates lies thus not in the definitions of the concepts that are contained in the postulates but rather in the fact that they force the reader to follow the instructions of a certain problem in such a way that she understands the truth of the proposition by solving the problem. ${ }^{6}$ Postulates, as Lambert conceives of them, are propositions that are proven by experience, which "can be renewed any time, as often as one doubts their validity". 69

Applied to the problem of metaphysics, this means that postulates are required to legitimately combine fundamental concepts, because they determine the extension and very possibility of a fundamental concept. Just as we can construct any line in geometry once we know how a line is constructed, one must, as Lambert states, find general rules for metaphysics that allow for the construction of a composite concept or axiom. ${ }^{70}$ What this means in particular in the Architectonic is that each of the eight fundamental concepts is accompanied by a certain number of postulates. After having introduced the "enumeration and immediate comparison" of simple concepts in the first part of the Architectonic, Lambert thus elaborates on the postulates that follow from such a comparison. ${ }^{71}$ Accordingly, the Architectonic formulates postulates of each simple concept on the basis of the possible relation of this concept to others, as outlined in the table of correlations. So, for instance, as we see in the tenth column, Lambert combines the concept of extension with the concept of unity. One of the postulates Lambert infers from extension reads: "Space has no particular unity". ${ }^{2}$ Without this postulate, metaphysics would have to examine the concept of extension in single case studies. ${ }^{73}$ By means of this postulate, however, philosophy can apply the concept 'extension' to any case.

\footnotetext{
${ }^{64}$ Euclid Elements, Book I, Definition 2; Book I, Postulate 2.

${ }^{65}$ Lambert differentiates between postulates and axioms in the following way: Postulates determine the general and unconditioned possibilities to form a complex concept on the basis of a simple one, while axioms indicate the limits of such possibilities (See Arch. § 13). While axioms build forth on the general possibilities determined by the postulates, postulates themselves are supposed to guarantee that the general rule (posited by the enunciation) can be applied to all particular cases. However, Lambert does not consistently differentiates between postulates and axioms, such that at other passages postulates seem to determine the limits of the possibility of a concept (Cf. Arch. § 76 and in contrast $\$ 123$ ). In is criterium veritatis, Lambert differentiates between axioms and postulates, however, the difference is not quite clear neither.

${ }^{66}$ Arch. § 18. See on the practical character of postulates Hintikka (1967: 361). Dunlop (2009: 52) argues that the practica character of postulates in Lambert's Architectonic corresponds with Wolff's conception of the will. This thesis could be strengthened by consulting the Systematology which Dunlop does not take into account. The Systematology implies that postulates are not only practical since they force the reader to understand a rule by means of the example of a special case but also, referring to Leibniz, since the will is involved in connecting subject and predicate. See Systematology, $\S 21$.

${ }^{67}$ See for the practical implication of postulates: Wolters $(1979: 45,88,90)$. Wolters elaborates here on the role of forces in Lambert's notion of postulates. Since postulates determine which act can successfully be executed, they imply the use of forces. Although I take forces to play an important role in Lambert's general view of ontology, I can't discuss them here in greater detail. In a letter to Holland, Lambert elucidates how he conceives of the application of the Euclidean postulates and axioms in geometry to metaphysics. (See Lambert's letter to Holland, April 21, 1765, (1782: 28, 29, 31, 32). See for the description of the mathematical method: Hintikka (1967: 361).

${ }^{68}$ Laywine points out that by showing the possibility of a figure, the possibility of its concepts is given at the same time, since, at least in geometry, one has to know what one is doing before doing so. See Laywine (2010: 119). Dunlop (2009: $52 \mathrm{f}$.) develops the thesis that with such a theory, Lambert tried to defend a system based on fundamental concepts against skepticism.

${ }^{69}$ Über die Methode, $\S 21$.

${ }^{70}$ See Lambert's letter to Hollande, April 21, 1765, (1782: 29); Org. Aleth. § 242.

${ }^{71}$ Arch. $\$ 76$.

${ }^{72}$ Arch. \& 79. Lambert discusses the postulates of every simple concept except for identity. See on the general possibility of postulates: Laywine (2010: 121). Dunlop (2009: 63) states that postulates provide fundamental concepts with their objects. However, I take Lambert's text not to justify such a reading.

${ }^{73}$ As postulates determine the possibility of a simple concept, they are, as Lambert states, to be understood as soon as the respective fundamental concept has been understood. Cf. Org. § 164.
} 


\subsection{Postulates and Ontology}

Lambert does not discuss the theory of postulates with regard to any science in particular, but takes it to be valid for all sciences that are mentioned in the table of correlations. On the basis of Lambert's statement that postulates "lay the ground for any scientific cognition", some commentators, such as Wolters, have argued that postulates (and for that matter Lambert's enterprise as a whole) only aim at guaranteeing the conditions of (natural) sciences in general. ${ }^{74}$ By contrast, I hold that Lambert was first and foremost interested in the possibility of saving the scientific status of ontology. I take this claim to be justified since Lambert discusses the advantages of postulates mostly in the context of his ontological project. Next to the above discussed function of postulates to secure the application of axioms, Lambert stresses the advantage postulates offer by comparing the results of several sciences. In this regard, Lambert highlights particularly the role of ontology. The results from ontology should, according to Lambert, serve as the basis for other sciences and conversely. ${ }^{75}$ Accordingly, the last parts of the Architectonic are larded with examples from ontology's influence on exact sciences. For example, in the fourth part - which deals with 'magnitude' - Lambert repeatedly stresses the importance of the mutual exchange between philosophy and mathematics. ${ }^{76}$ On my interpretation, such a discussion helps Lambert to stress on the one hand that ontology, as a science, improves by taking the results of other sciences (and especially of natural sciences) into account. On the other hand, it allows him to emphasize the necessity of a discipline such as ontology by highlighting its indispensable impact on other sciences.

It is with this twofold aim in view that Lambert discusses not only the relation between ontology and other sciences; but also between ontology and our everyday experience in the world. ${ }^{77}$ With his theory of postulates Lambert hopes to achieve what he promises in his theory of simple concepts - namely limiting the scope of ontology to what he calls "everyday life" [imgemeinen Leben $].{ }^{78}$ Ontology should not only concern logical truths, but should be applicable to the world. ${ }^{79}$ In addition to what has been argued above - namely that Lambert's ontology is based on the simple concept of solidity, instead of examining objects in general - the theory of postulates enables this role of ontology by allowing for the application of ontology's concepts to experience or, for that matter, historical cognition. This allows Lambert to put forward a new criterion for success with regard to ontology: Ontology no longer aims to support the claims of special metaphysics. Rather, it is supposed to provide principles that are ultimately applicable in experience. ${ }^{80}$ Lambert's new conception of ontology is mirrored in the modest expectations Lambert holds with regard to metaphysics in general. He states throughout the Organon and the Architectonic that the philosopher should be content with the limited results his research delivers. Reflecting upon his own work, Lambert rightfully stresses "the difference between former ontologies, including their order, and the present one". ${ }^{81}$ By means of his revised mathematical method Lambert thus hopes to have established

\footnotetext{
${ }^{74}$ Lambert's letter to Kant, February 3, 1766, (AA X: 66). Wolters (1969: 15-28).

${ }^{75}$ See Arch. Vorrede, X.

${ }^{76}$ Lambert stresses that both ontology and mathematics should exchange their methods and results, while he points at the same time to the importance of differentiating between them. See Arch. $\S$ 679-685; on the relation between ontology and mathematics see in particular Arch. $\S 881$ and 683.

${ }_{77}$ The question concerning the possibility of metaphysics as a science and in particular the method to be used in this regards experienced an upswing in Lambert's times. The prize essay contest, organized by the Berlin Academy of sciences shortly after Lambert's death, exemplifies the wide interest in this issue. For a detailed discussion of the development of the systematic method see Engfer (1982).

${ }^{78}$ Arch. Vorrede, IX

${ }^{79}$ See Arch. Vorrede, IX

${ }^{80}$ Lambert's new criterion of success for ontology forces him to provide a propaedeutic work which clarifies under which conditions a priori principles are applicable to experience. I take this propaedeutic to be delivered in his Architectonic. See on a discussion of the Architectonic and its propaedeutic function: Wellmann (2017).

81 Lambert (1787), Logische und philosophische Abhandlungen, 414. Lambert expressly stresses the difference between Baumgarten's definition of ontology for instance in $\S 4$ of Baumgarten'sMetaphysics and his own, for instance in $\S 3-13$ in the Architectonic. See Lambert (1787: 413, 114). Baumgarten, according to Lambert, searches for general predicates of being, while he, Lambert, aims at providing the first and simple grounds of cognition. Lambert might, however, have overlooked for instance $\S$ 5 of the Metaphysics, in which Baumgarten stresses the epistemological aspect of his ontology.
} 
an ontology that is essentially oriented towards experience: Based on simple concepts that are taken from experience and connected by means of practical postulates, it meets its ultimate demand, namely applyingits principles to experience again.

\section{Conclusion}

With this paper I hope to have shown that Lambert's discussion of Wolff's mathematical method is based on two criticisms which lead Lambert to a novel approach to metaphysics. Lambert tries on the one hand to revise Wolff's idea of fundamental concepts by providing what he takes to be a more profound theory of concepts. Instead of basing philosophy on general concepts, which are achieved by means of abstraction, Lambert bases his theory on simple concepts, which are taken directly from experience. On the other hand, Lambert introduces postulates. These practical instructions regulate the connection between simple concepts and account for their application to experience. Both transformations help Lambert to pursue Wolff's project of making metaphysics a science while avoiding at the same time the formality of Wolff's approach. This idea becomes especially apparent with regard to Lambert's notion of ontology. The aim of ontology, as Lambert sees it,is no longer to provide special metaphysics with its concepts. Rather, its ultimate criterion of success is that its principles are valid with regard to objects of experience. In this way, ontology becomes an independent science which constitutes one of those a priori sciences that Lambert takes to be exclusively oriented towards experience.

Bibliography

BAXMANN, Inge: Das Laokoon Paradigma. Zeichenregime im 18. Jahrhundert, Berlin, Akademie Verlag, 2000.

BASSO, Paola: "Rien de mathématique dans la methodus mathematica wolfienne. La méthode «mathématique» de Wolff et les objections de Lambert" in: Lumiéres. Christian Wolff et la pensée encyclopédique européenne, Bordeaux, Presses Universitaires de Bordeaux, 2008,109-121.

BECK, Lewis W.: "Lambert und Hume in Kants Entwicklung von 1769 - 1772”, Kant-Studien 60, 2, (1969), 123-130.

BIERBACH, Pier: Wissensrepräsentation - Gegenstände und Begriffe : Bedingungen des Antinomieproblems bei Frege und Chancen des Begriffssystems bei Lambert, Dissertation, 2001.

BLOMME, Henny: "La notion de 'système' chez Wolff, Lambert et Kant”, Estudos Kantianos 3, 1, (2015), 105-126.

BRANDT, Reinhard: “The table of Judgment. Critique of Pure Reason A 67-76; B 92-101”, North American Kant Society Studies in Philosophy 4, (1995), 1-147.

DUNLOP, Katherine: "Why Euclid's geometry brooked no doubt: J. H. Lambert on certainty and the existence of models", Synthese 167, 1, (2009), 33-65.

ENGFER, Hans-Jürgen: Philosophie als Analysis Studien zur Entwicklung philosophischer Analysiskonzeptionen unter dem Einfluss mathematischer Methodenmodelle im 17. und frühen 18. Jahrhundert, Stuttgart, Frommann-Holzboog, 1982.

HENRICH, Dieter: "Systemform und Abschlussgedanke - Methode und Metaphysik als Problem in Kants Denken", in: GERHARD, Volker (ed.): Kant und die Berliner Aufklärung, Boston, De Gruyter, 2001. 
HINTIKKA, Jaakko: "Kant on the Mathematical Method", The Monist 51, 3 (Kant Today: Part I), (1967), 352-375.

KAMBARTEL, Friedrich: "System und Begründung als wissenschaftliche und philosophische Ordnungsbegriffe bei und vor Kant” In: RITTER, J.; BLÜHDORN, J. (ed.): Philosophie und Rechtswissenschaft, Frankfurt am Main, Klostermann, (1969), 99-113.

LAMBERT, Johann H.: Über die Methode, die Metaphysik, Theologie und Moral richtieger zu beweisen, edited by K. Bopp, Berlin, Reuther und Reichard, 1918 [=Kantstudien, Ergänzungshefte 42]

LAMBERT, Johann H.: Neues Organon oder Gedanken über die Erforschung und Beziehung des Wahren und dessen Unterscheidung vom Irrthum und Schein, Teil I und II, Leipzig, 1764.

LAMBERT, Johann H.: Criterium Veritatis, edited by K. Bopp, Berlin, Reuther und Reichard, 1915. [=Kantstudien, Ergänzungshefte 36].

LAMBERT, Johann H.: Anlage zur Architektonik oder Theorie des Einfachen und Ersten in der philosophischen und mathematischen Erkenntniß, Riga, 1771.

LAMBERT, Johann H.: Fragment einer Systematologie. In: Texte zur Systematologie und zur Theorie der wissenschaftlichen Erkenntnis, edited by G. Siegwart, Hamburg, Meiner, 1988.

LAMBERT, Johann H.: Die Theorie der Parallellinien. Magazin für die reine und angewandte Mathematik, edited by J. Bernoulli, Berlin, Müller, Täubel, 1786.

LAMBERT, Johann H.: Logische und philosophische Abhandlungen, Teil II, Berlin, Bernoulli, 1782. Reprint: Hildesheim 1969. XII.

LAMBERT, Johann H.: Lamberts deutscher gelehrter Briefwechsel, Berlin/Leipzig, Bernoulli, 1782.

LAYWINE, Alison: "Kant and Lambert on geometrical postulates in the reform of metaphysics", In: FRIEDMAN, M.; DOMSKI, M. (ed.), Discourse on a New Method: Reinvigorating the Marriage of History and Philosophy of Science, Chicago, Open Court, 2010.

MANCHESTER, Paula: "Kant's Conception of Architectonic in its Historical Context", Journal of the History of Philosophy 41, 2, (2003), 187-207.

RIVERO, Gabriel: Zur Bedeutung des Begriffs Ontologie bei Kant, Berlin, De Gruyter, 2014.

ROS, Arno: “,Bedeutung“, „Idee“ und „Begriff“: Zur Behandlung einiger bedeutungstheoretischer Paradoxien durch Leibniz”, Studia Leibnitiana 21, 2, (1989), 133-154.

SIEGWART, Geo: Texte zur Systematologie und zur Theorie der wissenschaftlichen Erkenntnis, Hamburg, Meiner, 1988.

VOLLRATH, Ernst: "Die Gliederung der Metaphysik in eine metaphysica generalis und eine metaphysica specialis”, Zeitschrift für philosophische Forschung 16, 2, (1962), 258-284.

WAIBEL, Violetta: "Die Systemkonzeptionen bei Lambert und Wolff" in: STOLZENBERG, J. (ed.): Christian Wolff und die europäische Aufklärung, Teil 2, Hildesheim, Georg Olms, 2007.

WELLMANN, Gesa: "Lamberts Begriff eines metaphysischen Systems", Archiv für Begriffsgeschichte 58, (2017), in press.

WOLFF, Christian: Vernünftige Gedanken von den Kräften des menschlichen Verstandes und ihrem richtigen Gebrauche in Erkenntnis der Wahrheit, Hildesheim, Georg Olms, 1713/1987.

WOLFF, Christian: Ausführliche Nachricht von seinen eigenen Schriften, Frankfurt am Main, Andredische Buchhandlung, 1733. 
WOLFF, Christian: "De differentia intellectussystematici\& non-systematici". Translated, introduced and editied by M. Albrecht, Aufklärung. Interdisziplinäre Jahrbuch zur Erforschung des 18. Jahrunderts und seiner Wirkungsgeschichte 23, (1729/2011), 229-302.

WOLTERS, Gereon: Basis und Deduktion. Studien zur Entstehung und Bedeutung der Theorie der axiomatischen Methode bei J. H. Lambert (1728-1777), Berlin, de Gruyter, 1979.

ZÖLLER, Günter: ““'Die Seele des Systems”: Systembegriff und Begriffssystem in Kants Transzendentalphilosophie", in: FULDA, H. F.; STOLZENBERG, J. (eds.): Architektonik und System in der Philosophie Kants, Hamburg, Meiner, 2001, 54-72. 